\title{
Interaction of Traditional Remedies Against HIV, Nutrients and ARVs
}

\author{
Eugenia Barros \\ CSIR Biosciences, Meiring Naudee Road, Brummeria, Pretoria \\ South Africa
}

\section{Introduction}

South Africa is home to the world's largest population of people living with HIV/AIDs (5.7 million) and Sub-Saharan Africa is heavily affected with 22.4 million people living with the disease. Access to highly active antiretroviral (ARV) drugs is limited and many patients even when they are on ARVs consult traditional healers for herbal remedies. These traditional remedies as well as natural health products are widely used by HIV-infected patients in Southern Africa and other parts of the world.

The limitations and uncertainties surrounding the effectiveness of ARVs in the treatment of $\mathrm{HIV} / \mathrm{AIDS}$ have created a continuing search for new data on the possible drug-drug and drug-nutrient interactions. In this regard advances in the study of cytochrome P450, the enzyme system most commonly involved in drug metabolism, has provided mechanisms to investigate interactions of ARVs with natural health products and with nutrients in foods.

This chapter reviews some of the possible effects of certain foods of plant origin, including dietary supplements of herbal and botanical origin, indigenous foods and traditional medicines on the regulation of CYP450 enzyme activities, focusing on their possible interaction with ARV drugs. It also discusses future considerations surrounding the improvement of HIV/AIDS treatment management aiming at reducing resistance to ARV drugs and increase awareness of potential food-drug interactions that can render ARV treatment ineffective.

\section{CYP450, ARVs and nutrition}

The cytochrome P450 enzymes are the major catalysts in drug metabolism and one of the best characterized metabolic protein complexes (Wilkinson, 2005). Although in humans 57 CYP450 genes have been identified only a small number of the encoded proteins, mainly in the CYP1, CYP2 and CYP3 families, appear to contribute to the metabolism of clinically used drugs. CYP450 enzymes reduce or alter the pharmacologic activity of many drugs, attenuating its biological activity and facilitating or even accelerating its elimination from the body. They can also metabolize many chemicals present in the diet and in the environment (Wilkinson, 2005). The major site of CYP450 mediated metabolism is the liver but the enterocytes in the epithelium of the small intestine is also a potentially important site. The gastrointestinal track is the site where insoluble 'food/herb/natural products drug complexes' can be formed that can result in reduced drug efficacy. 


\subsection{Antiretrovirals (ARVs)}

The HIV virus uses three viral enzymes to replicate namely reverse transcriptase, protease and integrase. The current antiretroviral (ARV) drugs target the viral reverse transcriptase and the protease enzymes and are divided into four classes, nucleoside reverse transcriptase inhibitors (NRTIs), non-nucleoside reverse transcriptase inhibitors (NNRTIs) and HIV protease inhibitors (PIs); the fourth class of ARVs are the HIV fusion inhibitors that prevent virus-cell fusion and this way prevents infection of target cells (Cos et al., 2004). Some of the anti-HIV drugs that are in clinical use are shown in Table 1. Normally a cocktail is prepared by combining two nucleoside reverse transcriptase inhibitors with either one nonnucleoside transcriptase inhibitor or with one protease inhibitor in order to make a highly active ARV treatment (HAART) that has resulted in dramatic reductions of plasma virus levels (Anabwani \& Navario, 2005). These ARV drugs are predominantly metabolized by the CYP450 enzymes in families CYP3A, 4, 5 and 7; the HIV protease inhibitors are also substrates for the drug transporter P-glycoprotein.

The activity of CYP3A may be inhibited/reduced or induced as a result of drug interactions and this may have serious clinical implications. To try and minimize the problem of drug interactions, the identification and classification of many of the CYP3A substrates including the inhibitors and inducers of major clinical importance are available to clinicians so that an appropriate dosage strategy is found for each drug (Wilkinson, 2005). Rifampicin, a common drug used to treat tuberculosis, and some anticonvulsants are examples of drugs that induce CYP3A; so when these drugs are taken concurrently with HIV-protease inhibitors, therapeutic failure may occur as there is a marked reduction of the drug in the plasma. A similar situation can occur with non-prescription products like St John's wort, used in alternative medicine, and a potent inducer of CYP3A (Wilkinson, 2005). In addition drug toxicity can also happen as a result of overlapping toxicities from drugs used to treat opportunistic infections and ARVs (Anabwani \& Navario, 2005) as well as from drugs or traditional herbal medicines used to treat disorders associated with HIV-related problems like nausea, depression, insomnia, dermatological disorders, weakness and opportunistic infections (Mills, 2005b).

There are however instances where the inhibitory effect to CYP3A activity from a drug can be used for therapeutic advantage. This is the case of the ARV protease inhibitor, ritonavir, which is known to "significantly reduce CYP3A-mediated first-pass metabolism of certain inhibitors of HIV-encoded protease and substantially increases their levels in the plasma" (Wilkinson, 2005). This phenomenon has formed the basis of combining ritonavir with other protease inhibitors in the treatment of HIV-1 infection.

\subsection{Traditional remedies and herbal medicines}

Traditional medicines make use of the therapeutic power of plants and herbs and are widely used in Africa and in South Africa by traditional practitioners/healers, offering an alternative choice for the treatment of a variety of ailments and diseases. Some of the natural products and herbs that are used in traditional medicine are shown in Table2; some of their most common applications are also indicated.

Plant extracts known to have antimicrobial properties have been found to be synergistic enhancers when taken in combination with standard drugs. In some cases the synergistic properties were only found to be effective when plant antimicrobials were taken concurrently with standard drugs, enhancing the effect of the drug. Kamatou et al., (2006) reported on the effectiveness of two plants, Salvia chamelaeagnea and Leonotis leonurus against 


\begin{tabular}{|c|c|c|c|}
\hline \multicolumn{4}{|c|}{ Nucleoside reverse transcriptase inhibitors (NRTIs) } \\
\hline Generic name & Trade names & $\begin{array}{l}\text { Availability in } \\
\text { South Africa }\end{array}$ & Regimen in South Africa \\
\hline Didanosine & $\begin{array}{l}\text { Videx, ddl, Sspen- } \\
\text { Didanosine }\end{array}$ & Yes & \begin{tabular}{|c}
\multicolumn{2}{|c}{ Paediatric HIV infection } \\
regimen 2 \\
Adult HIV infection regimen 2 \\
\end{tabular} \\
\hline Emtricitabine & Emtriva, FTC & No & Not available \\
\hline Lamivudine & $\begin{array}{l}\text { Epivir, 3TC, Cipla- } \\
\text { Lamivudine, } \\
\text { Aspen-Lamivudine }\end{array}$ & Yes & $\begin{array}{c}\text { Paediatric HIV infection } \\
\text { regimen } 1 \\
\text { Adult HIV infection regimen } 1\end{array}$ \\
\hline Stavudine & $\begin{array}{l}\text { Zerit, d4T, Stavir, } \\
\text { Aspen-Stavudine }\end{array}$ & Yes & $\begin{array}{c}\text { Paediatric HIV infection } \\
\text { regimen } 1 \\
\text { Adult HIV infection regimen } 1\end{array}$ \\
\hline Zalcitabine & Hivid, ddC & Yes & $\begin{array}{l}\text { Not currently part of SA } \\
\text { guidelines }\end{array}$ \\
\hline Zidovudine & $\begin{array}{l}\text { Retrovir, AZT, } \\
\text { ZDV,Aspen- } \\
\text { Zidovudine }\end{array}$ & Yes & $\begin{array}{c}\text { Paediatric HIV infection } \\
\text { regimen } 2 \\
\text { Adult HIV infection regimen } 2\end{array}$ \\
\hline Abacavir & Ziagen & Yes & $\begin{array}{l}\text { Adult and paediatric HIV } \\
\text { infection } \\
\text { Used in combination with other } \\
\text { NRTIs }\end{array}$ \\
\hline Tenofovir & Viread & Yes & No guidelines available \\
\hline \multicolumn{4}{|c|}{ Non-nucleoside reverse transcriptase inhibitors (NNRTIs) } \\
\hline Generic name & Trade names & $\begin{array}{l}\text { Availability in } \\
\text { South Africa }\end{array}$ & Regimen in South Africa \\
\hline Delavirdine & Rescriptor & Yes & Not frequently used \\
\hline Nevirapine & Viramune & Yes & Adult HIV infection regimen 1 \\
\hline Efavirenz & Sustiva, Stocrin & Yes & \begin{tabular}{|c|} 
Paediatric HIV infection \\
regimen 1 \\
Adult HIV infection regimen 1 \\
\end{tabular} \\
\hline \multicolumn{4}{|c|}{ Protease inhibitors (PIs) } \\
\hline Generic name & Trade names & $\begin{array}{l}\text { Availability in } \\
\text { South Africa }\end{array}$ & Regimen in South Africa \\
\hline Indinavir & Crixivan & Yes & No guidelines available \\
\hline Nelfinavir & Viracept & Yes & No guidelines available \\
\hline Ritonavir & Norvir & Yes & No guidelines available \\
\hline Saquinavir & $\begin{array}{l}\text { Invirase is a hard- } \\
\text { gel capsule; } \\
\text { Fortovase is a soft- } \\
\text { gel capsule }\end{array}$ & Yes & No guidelines available \\
\hline Amprenavir & Agenerase & Yes & No guidelines available \\
\hline Atazanavir & Reyataz & Yes & No guidelines available \\
\hline $\begin{array}{l}\text { Fosamprenavir } \\
\text { calcium }\end{array}$ & Lexiva & Yes & No guidelines available \\
\hline
\end{tabular}




\begin{tabular}{|c|c|c|c|}
\hline \multicolumn{4}{|c|}{ Fusion inhibitors } \\
\hline Generic name & Trade names & $\begin{array}{l}\text { Availability in } \\
\text { South Africa }\end{array}$ & Regimen in South Africa \\
\hline Enfuvirtide & Fuzeon, T-20 & No & Not available \\
\hline \multicolumn{4}{|c|}{ Combinations of NRTIs, NNRTIs and PIs } \\
\hline Combinations & Trade names & $\begin{array}{c}\text { Availability in } \\
\text { South Africa }\end{array}$ & Regimen in South Africa \\
\hline Combination of NRTI & $\begin{array}{l}\text { Abacavir + } \\
\text { Lamivudine }\end{array}$ & Yes & No guidelines available \\
\hline $\begin{array}{c}\text { Combination of NRTI } \\
\text { (Combivir, Avacomb, } \\
\text { Aspen-Lamzid) }\end{array}$ & $\begin{array}{l}\text { Zidovudine + } \\
\text { Lamivudine }\end{array}$ & Yes & No guidelines available \\
\hline Combination of NRTI & $\begin{array}{l}\text { Abacavir + } \\
\text { Zidovudine }\end{array}$ & $\begin{array}{l}\text { Yes (less } \\
\text { common) }\end{array}$ & No guidelines available \\
\hline Combination of NRTI & $\begin{array}{l}\text { Didanosine + } \\
\text { Zidovudine }\end{array}$ & $\begin{array}{l}\text { Yes (less } \\
\text { common) }\end{array}$ & No guidelines available \\
\hline Combination of NRTI & $\begin{array}{l}\text { Stavudine + } \\
\text { Lamivudine }\end{array}$ & $\begin{array}{l}\text { Yes (less } \\
\text { common) }\end{array}$ & No guidelines available \\
\hline $\begin{array}{c}\text { Combination NRTI + } \\
\text { NNRTI }\end{array}$ & $\begin{array}{c}\text { Tenofovir }+ \\
\text { Lamivudine }+ \\
\text { Efavirenz }\end{array}$ & Yes & $\begin{array}{l}\text { Adult } \mathrm{HIV} \text { infection } 1^{\text {st }} \text { line } \\
\text { regimen } 1\end{array}$ \\
\hline $\begin{array}{c}\text { Combination NRTI + } \\
\text { NNRTI }\end{array}$ & $\begin{array}{c}\text { Tenofovir }+ \\
\text { Lamivudine }+ \\
\text { Nevirapine } \\
\end{array}$ & Yes & $\begin{array}{l}\text { Adult } \mathrm{HIV} \text { infection } 1^{\text {st }} \text { line } \\
\text { regimen } 2\end{array}$ \\
\hline $\begin{array}{c}\text { Combination NRTI + } \\
\text { NNRTI }\end{array}$ & $\begin{array}{c}\text { Stavudine }+ \\
\text { Lamivudine }+ \\
\text { Efavirenz } \\
\end{array}$ & Yes & $\begin{array}{l}\text { Adult } \mathrm{HIV} \text { infection } 1^{\text {st }} \text { line } \\
\text { regimen } 3\end{array}$ \\
\hline $\begin{array}{c}\text { Combination NRTI + } \\
\text { NNRTI }\end{array}$ & $\begin{array}{l}\text { Stavudine }+ \\
\text { Lamivudine }+ \\
\text { Nevirapine }\end{array}$ & Yes & $\begin{array}{l}\text { Adult HIV infection } 1^{\text {st }} \text { line } \\
\text { regimen } 4\end{array}$ \\
\hline $\begin{array}{c}\text { Combination NRTI + } \\
\text { NNRTI }\end{array}$ & $\begin{array}{c}\text { Zidovudine + } \\
\text { Lamivudine }+ \\
\text { Efavirenz } \\
\end{array}$ & Yes & $\begin{array}{l}\text { Adult } \mathrm{HIV} \text { infection } 1^{\text {st }} \text { line } \\
\text { regimen } 5\end{array}$ \\
\hline $\begin{array}{c}\text { Combination NRTI + } \\
\text { NNRTI }\end{array}$ & $\begin{array}{c}\text { Zidovudine }+ \\
\text { Lamivudine }+ \\
\text { Nevirapine } \\
\end{array}$ & Yes & $\begin{array}{l}\text { Adult } \mathrm{HIV} \text { infection } 1^{\text {st }} \text { line } \\
\text { regimen } 6\end{array}$ \\
\hline $\begin{array}{l}\text { Combination of PIs } \\
\text { (Kaletra, LPV/r) }\end{array}$ & $\begin{array}{l}\text { Lopinavir + } \\
\text { Ritonavir }\end{array}$ & Yes & $\begin{array}{c}\text { Paediatric HIV infection } \\
\text { regimen } 1 \\
\text { Adult HIV infection regimen } 2 \\
\end{array}$ \\
\hline
\end{tabular}

Table 1. List of some of the anti-HIV drugs belonging to the four classes of ARVs in clinical use (Cos et al., 2004). The information relating to the drug availability and regimen in South Africa is from the South African Department of Health (www.doh.gov.za/docs/misc./hiv/manual/pharmacoloy_art.pdf) 
Gram +ve bacteria when taken in combination than when they were taken individually. Aiyegon \& Okoho (2009) reviewed the use of several bioactive plant products in combination with standard antibiotics demonstrating its application in antimicrobial chemotherapy. However they also cautioned on the possible problems related to toxicity and overdose as less concentration of the two products will be required when they are taken in combination.

Information on the systems whereby bioactive plant products are metabolized is not readily available; future studies should be encouraged to ensure that better results can be obtained from the combined use of medicinal plants and the drugs used in orthodox medicine. It is necessary to understand what kind of interactions are possible and how best to avoid them so that that the maximum benefits are derived from the substances people ingest with the least possible risk.

\begin{tabular}{|c|c|c|c|}
\hline Plant & $\begin{array}{l}\text { Common } \\
\text { name }\end{array}$ & Applications and traditional uses & References \\
\hline $\begin{array}{l}\text { Allium } \\
\text { sativum }\end{array}$ & Garlic & $\begin{array}{l}\text { Anti-microbial and antispasmodic properties; } \\
\text { antioxidant }\end{array}$ & $\begin{array}{l}\text { Mills \& Bone, } \\
2000\end{array}$ \\
\hline $\begin{array}{l}\text { Aspalathus } \\
\text { linearis }\end{array}$ & $\begin{array}{c}\text { Rooibos tea } \\
\text { Rooibos' } \\
\text { extracts }\end{array}$ & $\begin{array}{c}\text { Healthy drink; help with stomach cramp and } \\
\text { vomiting in infantile colic; antioxidant } \\
\text { Alleviate dermatological problems e.g. } \\
\text { eczema, skin allergies }\end{array}$ & $\begin{array}{l}\text { Joubert et al., } \\
2008\end{array}$ \\
\hline $\begin{array}{c}\text { Athrixia } \\
\text { phylicoides }\end{array}$ & Bush tea & $\begin{array}{l}\text { Herbal tea; treatment of boils, acne, throat } \\
\text { infections, infected wounds }\end{array}$ & $\begin{array}{l}\text { Joubert et al., } \\
2008 \\
\end{array}$ \\
\hline $\begin{array}{c}\text { Catharanthus } \\
\text { roseus }\end{array}$ & - & $\begin{array}{c}\text { Treatment of many disorders including } \\
\text { diabetes, malaria, inflammation and } \\
\text { hypertension }\end{array}$ & $\begin{array}{l}\text { van den Bout- } \\
\text { van den Beukel } \\
\text { et al., } 2006\end{array}$ \\
\hline Cyclopia spp & $\begin{array}{c}\text { Honeybush } \\
\text { tea }\end{array}$ & $\begin{array}{l}\text { Health booster; alleviate chronic catarrh and } \\
\text { pulmonary tuberculosis }\end{array}$ & $\begin{array}{l}\text { Joubert et al., } \\
2008\end{array}$ \\
\hline $\begin{array}{l}\text { Harpagophytu } \\
\text { m procumbens }\end{array}$ & Devil's claw & $\begin{array}{l}\text { Pain killer, improves flexibility and mobility } \\
\text { associated with rheumatic diseases }\end{array}$ & $\begin{array}{l}\text { van den Bout- } \\
\text { van den Beukel } \\
\text { et al., } 2006\end{array}$ \\
\hline $\begin{array}{l}\text { Echinacea } \\
\text { purpurea }\end{array}$ & $\begin{array}{c}\text { Echinacea / } \\
\text { Purple } \\
\text { coneflower }\end{array}$ & $\begin{array}{l}\text { Immune tonic; treatment of upper respiratory } \\
\text { infections; anti-inflammatory }\end{array}$ & Barret, 2003 \\
\hline $\begin{array}{l}\text { Hydrastis } \\
\text { canadensis }\end{array}$ & $\begin{array}{c}\text { Goldenseal } \\
\text { root }\end{array}$ & $\begin{array}{l}\text { Immune booster; antimicrobial ; anti- } \\
\text { inflamatory }\end{array}$ & $\begin{array}{l}\text { Sandhu et al., } \\
2003\end{array}$ \\
\hline $\begin{array}{c}\text { Hypoxis } \\
\text { hemerocallidea }\end{array}$ & $\begin{array}{l}\text { African } \\
\text { potato }\end{array}$ & $\begin{array}{c}\text { Antioxidant properties, treatment urinary } \\
\text { infections, nervous disorders, cancer, HIV- } \\
\text { AIDS }\end{array}$ & $\begin{array}{l}\text { Mills et al., } \\
\text { 2005a }\end{array}$ \\
\hline $\begin{array}{l}\text { Hypericum } \\
\text { perforatum }\end{array}$ & $\begin{array}{l}\text { St. John's } \\
\text { wort }\end{array}$ & Treatment of depression & Lee et al., 2006 \\
\hline $\begin{array}{l}\text { Sutherlandia } \\
\text { frutescens }\end{array}$ & $\begin{array}{l}\text { Cancer } \\
\text { bush }\end{array}$ & $\begin{array}{l}\text { Anti-viral activity including retroviruses } \\
\text { Anti-inflammatory properties } \\
\text { Treatment of stress related maladies } \\
\end{array}$ & $\begin{array}{l}\text { Mills et al., } \\
\text { 2005a }\end{array}$ \\
\hline
\end{tabular}

Table 2. Some of the natural products and herbs used in traditional medicine with some of their most common applications 


\subsection{Nutrients in foods including indigenous foods and dietary supplements}

In addition to drug-drug interactions observed when drugs are metabolized by the same CYP450 enzyme system interactions between foods and drugs have also been reported and have been responsible for drug dosage adjustments in order to maintain drug concentrations within its therapeutic window (Jang et al., 2004).

The various phases in which foods or dietary supplements may interact with coadministered drugs are during gastrointestinal absorption, distribution, metabolism and elimination (Jang et al., 2004). The metabolic phase is particularly important in food-drug interactions where the consumption of particular foods modulates the activity of a drugmetabolizing enzyme system, resulting in an alteration in the pharmacokinetics of the drugs metabolized by that system (Jang et al., 2004). Some foods and dietary supplements that contain complex mixtures of phyto-chemicals have the greatest potential to induce or inhibit the expression and activity of drug-metabolizing enzymes.

The interaction between HIV/AIDS and nutrition is particularly important as severe malnutrition impairs immune function and decreases resistance to infection. The immune cells depend on metabolic pathways that use various nutrients as critical cofactors for their actions and activities; during deficiencies of trace elements, of vitamins or when there is protein-calorie malnutrition, the individual defence mechanism is compromised. In developing countries micronutrient deficiencies are particularly common in HIV-infected individuals and several studies have shown that low serum levels of vitamin A poses a great risk for the rapid progression of the disease towards development of AIDS and then death (Anabwani et al., 2005).

In order to address nutrient deficiencies in HIV-infected persons, particularly in developing countries, the consumption of a varied diet using foods high in nutritional value including protein, micronutrients and phytochemicals that are available in their communities has been encouraged. For the most vulnerable communities the available foods are primarily indigenous foods. There is very little known about the nutrient composition of some of the indigenous foods and about the interaction of the specific nutrients with ARVs. More efforts are being made to identify and analyse specific nutrients of indigenous foods in an attempt to increase awareness of potential food-drug interactions and maximize effectiveness of ARVs.

Some of the traditional foods that are eaten in different parts of South Africa include pumpkin leaves with or without pumpkin seeds; amaranthus leaves; jugo beans; wild melon; bean mix made up of jugo beans, brown beans and maize; masonja made up of mopani and nuts; tihove made up of samp, nuts, cowpeas and beans; nyaka made up of wheat, sorghum, beans and peas; madumbe; corchorus; cleome and nightshade (T. Moroka, personal communication). In our laboratories we are in the process of evaluating plant food extracts from indigenous and traditional foods and remedies to determine the ability of these extracts to inhibit human CYP450 enzyme activities, especially CYP3A4, using in vitro assays. This study will contribute to the evaluation of the impact that these foods can have in HIV-infected individuals if consumed at the same time as the ARV drugs are taken.

\subsection{Possible therapeutic failure or development of drug resistance}

Drug-drug interactions have become an important issue in health care where drug resistance or treatment failure is always a concern. As dietary and nutrient supplementation strategies are considered in the treatment of HIV infection it aims to take advantage of the mixture of active compounds derived from plant/herb extracts and ARVs to produce the 
desired clinical effect. The same applies to the active ingredients in foods including indigenous foods; proper analysis should be done to determine the enzyme system by which these nutrients are metabolized and this way prevent any alteration in the pharmacokinetics of the ARVs.

Clinical studies using drugs and herbal medicines with the same metabolic route as ARVs have shown to have the potential to significantly interact with ARV metabolism through the modulation of hemethiolate-containing enzymes of the CYP450 system, in particular CYP3A4 activity. Hypoxis hemerocallidea, commonly known as African potato, and Sutherlandia, are two botanical supplements widely used in Sub-Saharan Africa that have been reported to potentially increase drug toxicity, viral resistance and treatment failure when used in conjunction with ARVs (Mills et al., 2005a).

The marked inhibitory effect of grapefruit juice with a number of orally administered drugs that are substrates to CYP3A4 was first reported by Bailey et al., (2003). Further investigations confirmed that due to its interaction with prescribed drugs where the peak of a drug level could be increased by a factor of three without any change in the half-life of the medication, grapefruit is contra-indicated in patients receiving drugs that are mainly metabolized by CYP3A4 (Jang et al., 2004). There are many other reports where treatment is rendered ineffective because of unknown interactions between nutrients and prescribed drugs and it is particularly important when the total drug absorption is altered (Bibi, 2008). Drug toxicity also exists with drugs that are modulated by CYP1A2 when co-administered with CYP1A2 dietary supplements. Jan et al. (2004) reported a study done on patients taking certain drugs that are metabolized by CYP1A2 (acetaminophen, imipramine, theophylline, estradiol or warfarin). When these drugs were taken concurrently with CYP1A2 dietary supplements the patients' ability to metabolize the drugs was considerably lowered and could have resulted in drug toxicity. On the other hand when these drugs were taken concurrently with CYP1A2-inducing dietary supplements, the patients' ability to metabolize the drugs was greater causing them to be eliminated faster, resulting in reduced pharmaceutical activity (Jang et al., 2004). However for the purpose of this short review emphasis was placed on reports of drug-food interactions with drugs and foods that are modulated by the same CYP450 enzyme systems used by the commonly used ARVs in Africa.

A study of herb-drug interactions between five Malaysian medicinal plants and drugs metabolized by CYP2C9, CYP2D6 and CYP3A4 showed that Orthosiphon stamineus, Mitragyna speciosa and Andrographis paniculta were potential inhibitors of the three enzyme activities, suggesting that these medicinal plants should not be used simultaneously with these classes of drugs (Hanapi et al., 2010). Two other plants Eurycoma longifolia and Mitragyna speciosa showed no significant inhibition suggesting that they can be taken concurrently with ARVs. These tests were done using an in vitro assay system that contains recombinant human CYP450 enzyme; this is the same in vitro system that is being used in our laboratories as it is sufficiently robust to handle many samples at the same time (E. Barros, personal communication).

Rooibos (Aspalathis linearis) tea and honeybush (Cyclopia intermedia) tea are natural herbs indigenous to South Africa that have been widely used as herbal remedies for a wide range of ailments. The antioxidant properties of the teas and plant extracts from these two plants are important in boosting the human immune system; these antioxidants protect cells against oxidative damage by scavenging for free radicals. However the simultaneous intake of rooibos and honeybush with certain ARV drugs should be taken with caution due to the 


\begin{tabular}{|c|c|c|c|c|}
\hline $\begin{array}{c}\text { Plant/herb } \\
\text { name }\end{array}$ & \begin{tabular}{|c|} 
Test \\
system \\
\end{tabular} & $\begin{array}{c}\text { Relevant chemical } \\
\text { constituents (bioactive) }\end{array}$ & \begin{tabular}{|c|} 
Effect on CYP3A4 \\
enzyme system or P-gp
\end{tabular} & References \\
\hline \begin{tabular}{|c|} 
American \\
Ginseng \\
(Panax \\
quinquefolius) \\
\end{tabular} & In vitro & $\begin{array}{l}\text { Ginsenoside, } \\
\text { propanaxatriol } \\
\text { ginsenoside }\end{array}$ & Inhibition CYP3A4 & $\begin{array}{l}\text { van den Bout- } \\
\text { van den Beukel } \\
\text { et al., } 2006\end{array}$ \\
\hline $\begin{array}{l}\text { Asian } \\
\text { Ginseng } \\
\text { (Panax } \\
\text { ginseng) }\end{array}$ & In vitro & $\begin{array}{l}\text { Ginsenoside, } \\
\text { propanaxatriol } \\
\text { ginsenoside }\end{array}$ & Inhibition CYP3A4 & $\begin{array}{l}\text { van den Bout- } \\
\text { van den Beukel } \\
\text { et al., } 2006\end{array}$ \\
\hline \begin{tabular}{|c|} 
African \\
potato \\
(Hypoxis \\
hemerocallidea) \\
\end{tabular} & In vitro & $\begin{array}{l}\text { Hypoxoside which is } \\
\text { converted into rooperol }\end{array}$ & $\begin{array}{l}\text { Increase inhibition by } \\
\text { 86\% CYP3A4 }\end{array}$ & $\begin{array}{l}\text { Mills et al., } \\
\text { 2005a, 2005b }\end{array}$ \\
\hline $\begin{array}{l}\text { Catharanthus } \\
\text { roseus }\end{array}$ & In vitro & $\begin{array}{l}\text { Ajmalicine and } \\
\text { serpentine }\end{array}$ & $\begin{array}{l}\text { Weak or no inhibitory } \\
\text { effect CYP3A4 }\end{array}$ & $\begin{array}{c}\text { van den Bout- } \\
\text { van den Beukel } \\
\text { et al., } 2006 \\
\end{array}$ \\
\hline \begin{tabular}{|c|} 
Seville orange \\
(Citrus \\
aurantium)
\end{tabular} & $\begin{array}{l}\text { In vivo } \\
\text { In vitro }\end{array}$ & $\begin{array}{l}- \\
-\end{array}$ & $\begin{array}{c}\text { Inhibition P-gp } \\
\text { Inhibition CYP3A4 }\end{array}$ & $\begin{array}{c}\text { Tarirai et al., } \\
2010\end{array}$ \\
\hline Devil's claw & In vitro & Harpagoside & Inhibition CYP3A4 & $\begin{array}{c}\text { van den Bout- } \\
\text { van den Beukel } \\
\text { et al., } 2006 \\
\end{array}$ \\
\hline Echinacea & In vitro & Quercetin & Inhibition CYP3A4 & $\begin{array}{c}\text { van den Bout- } \\
\text { van den Beukel } \\
\text { et al., } 2006 \\
\end{array}$ \\
\hline \begin{tabular}{|c|} 
Eucalyptus oil \\
(Eucalyptus \\
globules)
\end{tabular} & In vitro & Cineole & Inhibition CYP3A4 & $\begin{array}{c}\text { van den Bout- } \\
\text { van den Beukel } \\
\text { et al., } 2006 \\
\end{array}$ \\
\hline $\begin{array}{l}\text { Evening } \\
\text { primrose }\end{array}$ & In vitro & $\begin{array}{c}\text { Linoleic acid, oleic acid, } \\
\text { palmitic acid, stearic } \\
\text { acid }\end{array}$ & $\begin{array}{l}\text { Moderate inhibition } \\
\text { CYP3A4 }\end{array}$ & $\begin{array}{c}\text { van den Bout- } \\
\text { van den Beukel } \\
\text { et al., } 2006 \\
\end{array}$ \\
\hline Garlic & $\begin{array}{c}\text { In vitro } \\
\text { and In } \\
\text { vivo } \\
\text { Clinical } \\
\text { studies } \\
\text { In vivo }\end{array}$ & $\begin{array}{l}\text { Alliin, allicin } \\
\text { Garlic extracts } \\
\text { Garlic extracts }\end{array}$ & $\begin{array}{c}\text { Weak inhibition } \\
\text { CYP3A4 } \\
\text { Induction CYP3A4 and } \\
\text { P-gp } \\
\text { No significant } \\
\text { inhibition of CYP3A4 } \\
\end{array}$ & $\begin{array}{c}\text { Tarirai et al., } \\
2010 \\
\text { Piscitelli et al., } \\
2002 \\
\text { Markowitz et al., } \\
2003 \\
\end{array}$ \\
\hline $\begin{array}{l}\text { Ginger } \\
\text { (Zingiber } \\
\text { officinale) }\end{array}$ & $\begin{array}{c}\text { Case } \\
\text { report }\end{array}$ & $\begin{array}{c}\text { Gingerols, zingiberene, } \\
\text { shoagols, }\end{array}$ & Inhibition CYP3A4 & $\begin{array}{c}\text { van den Bout- } \\
\text { van den Beukel } \\
\text { et al., } 2006 \\
\end{array}$ \\
\hline $\begin{array}{c}\text { Ginkgo } \\
(\text { Ginkgo biloba })\end{array}$ & In vitro & Ginkgolic acids & $\begin{array}{c}\text { Inhibition CYP3A4 and } \\
\text { P-gp }\end{array}$ & $\begin{array}{l}\text { van den Bout- } \\
\text { van den Beukel } \\
\text { et al., } 2006\end{array}$ \\
\hline
\end{tabular}




\begin{tabular}{|c|c|c|c|c|}
\hline $\begin{array}{l}\text { Goldenseal } \\
\text { root } \\
\text { (Hydrastis } \\
\text { canadensis) }\end{array}$ & $\begin{array}{l}\text { In vitro } \\
\text { Clinical } \\
\text { studies }\end{array}$ & Isoquinoline alkaloids & $\begin{array}{c}\text { Inhibition CYP3A4 } \\
\text { No effect on CYP3A4 } \\
\text { nor P-gp }\end{array}$ & $\begin{array}{l}\text { Sandhu et al., } \\
2003 \\
\text { Lee et al., } 2006\end{array}$ \\
\hline $\begin{array}{l}\text { Grapefruit } \\
\text { juice } \\
\text { (Citrus } \\
\text { paradise) }\end{array}$ & $\begin{array}{l}\text { In vivo } \\
\text { In vitro } \\
\text { and in } \\
\text { vivo }\end{array}$ & $\begin{array}{l}\text { Naringenin; } \\
\text { furanocoumarin } \\
\text { bergamottin; } \\
\text { Diosmin }\end{array}$ & $\begin{array}{c}\text { Inhibition CYP3A4 } \\
\text { Induction CYP3A4 and } \\
\text { P-gp }\end{array}$ & $\begin{array}{l}\text { Tarirai et al., } \\
2010\end{array}$ \\
\hline $\begin{array}{l}\text { Milk thistle } \\
\text { (Silybum } \\
\text { marianum) }\end{array}$ & $\begin{array}{l}\text { In vitro } \\
\text { Clinical } \\
\text { studies }\end{array}$ & $\begin{array}{c}\text { Isoprenoid } \\
\text { dihydrosilybins, } \\
\text { silymarin, sylibinins, } \\
\text { taxifolin, } \\
\text { apigenin,luteolin }\end{array}$ & Induction P-gp & $\begin{array}{c}\text { Tarirai et al., } \\
2010 \\
\text { van den Bout- } \\
\text { van den Beukel } \\
\text { et al., } 2006 \\
\end{array}$ \\
\hline Rooibos tea & In vivo & Pinitol & Induction CYP3A & $\begin{array}{l}\text { Matsuda et } \\
\text { al.,2007 }\end{array}$ \\
\hline $\begin{array}{c}\text { Soy } \\
\text { (Glyvine max) }\end{array}$ & In vitro & $\begin{array}{l}\text { Genistein, daidzen } \\
\text { (phytoestrogen) }\end{array}$ & $\begin{array}{c}\text { Inhibition CYP3A4 and } \\
\text { P-gp }\end{array}$ & $\begin{array}{l}\text { van den Bout- } \\
\text { van den Beukel } \\
\text { et al., } 2006 \\
\end{array}$ \\
\hline St John's wort & In vitro & $\begin{array}{l}\text { Hyperforin, hypericin, } \\
\text { quercetin, isoquercetin, } \\
\text { biflavonoids, } \\
\text { naphthoadianthrones, } \\
\text { catechins, tannins }\end{array}$ & $\begin{array}{c}\text { Induction CYP3A4 and } \\
\text { P-gp }\end{array}$ & $\begin{array}{l}\text { Piscitelli et } \\
\text { al.,2000 } \\
\text { Mannel, } 2004\end{array}$ \\
\hline Sutherlandia & In vitro & $\begin{array}{l}\text { L-canavanine that is an } \\
\text { arginine analogue }\end{array}$ & $\begin{array}{c}\text { Near complete } \\
\text { inhibition }(96 \%) \\
\text { CYP3A4 } \\
\text { Inhibition P-gp }\end{array}$ & \begin{tabular}{|c|} 
Mills et al., 2005a \\
van den Bout- \\
van den Beukel \\
et al., 2006 \\
\end{tabular} \\
\hline $\begin{array}{c}\text { Cranberry } \\
\text { juice } \\
\text { (Vaccinium } \\
\text { macrocarpon) }\end{array}$ & In vitro & $\begin{array}{l}\text { Flavonoids } \\
\text { (antioxidants) }\end{array}$ & Inhibition CYP3A4 & $\begin{array}{l}\text { van den Bout- } \\
\text { van den Beukel } \\
\text { et al., } 2006\end{array}$ \\
\hline $\begin{array}{l}\text { Valerian } \\
\text { (Valeriana } \\
\text { officinalis) }\end{array}$ & In vitro & $\begin{array}{c}\text { Isovalerianic or valerenic } \\
\text { acid }\end{array}$ & $\begin{array}{c}\text { Inhibitor CYP3A4 and } \\
\text { P-gp }\end{array}$ & $\begin{array}{c}\text { van den Bout- } \\
\text { van den Beukel } \\
\text { et al., } 2006\end{array}$ \\
\hline
\end{tabular}

Table 3. Examples of plant and herbal products used with ARVs in the treatment of HIVAIDs with reference to metabolism by CYP450 3A4 and/or P-glycoprotein (P-gp)

induction of CYP3A4 activity (Mashuda et al., 2007); they should be taken preferably at different times. Table 3 contains some examples of plant and herbal products used with ARVs in the treatment of HIV-AIDs with reference to metabolism by CYP450 3A4 and/or Pglycoprotein (P-gp).

The concurrent use of natural health products with ARVs is also widespread and there are varied reports on the level of interaction with certain natural health products resulting in changes in the efficacy of the ARV treatment. Natural health products are often complex mixtures containing organic compounds many of which can induce and/or inhibit the enzymatic pathways involved in the metabolism of ARV drugs (Lee et al., 2006). 
St. John's wort, a well known natural health product, is commonly used by HIV-infected patients due to its antidepressant properties. One of its constituents, hyperforin, is a very active inducer of CYP3A4 activity and responsible for a reduction in drug activity. Mannel (2004) reported a case of a reduction in the activity of an ARV drug cocktail containing indinavir-lamivudine-stavudine when it was co-administered with St John's wort. A similar interaction of St John's wort was reported with the co-administration of two separate ARVs namely indinavir and nevirapine (Lee et al., 2006).

Garlic is another natural health product commonly used by HIV-infected patients where reports have shown different types of interactions with different ARVs. A decrease in the plasma concentration of fortovase, the soft gel formulation of saquinavir, was found in patients taking garlic while on fortovase treatment possibly due to induction of intestinal CYP3A4 and/or P-gp (Piscitelli et al., 2002). Another report of the concurrent intake of garlic supplements by an HIV-infected patient on ritonavir therapy suggested inhibition of garlic metabolism caused by ritonavir leading to potential garlic toxicity (Lee et al., 2006). Other in vivo and in vitro studies on the pharmacokinetic interactions of garlic with ARVs have reported either a slight reduction or no effect on CYP3A4 activity. The variation observed with the co-administration of garlic and the different ARVs are possibly due to the different garlic constituents present in the various garlic supplements.

Vitamins are another group of natural health products widely used by patients on ARV therapy. However evaluation of the pharmacokinetic interactions between vitamins and ARVs is very complex as not only there are many vitamins but there are also different combinations of vitamins, different doses and they can also be administered singly or in a multivitamin form. So vitamins tend to be evaluated singly. The two most commonly tested vitamins are Vitamin C and Vitamin E. A study of the interaction between Vitamin C and indinavir done on healthy people using a high dosage of Vitamin C (1000 mg/day) showed a reduction in the plasma concentration of indinavir. A variation was however observed in the level of bioavailable indinavir among the different individuals (Slain et al., 2005). This interaction would lead to treatment failure in HIV-infected individuals.

Goldenseal root was reported to cause a strong inhibition in the activity of CYP3A4 using in vitro studies (Lee et al., 2006), yet when clinical tests were done on the interaction between goldenseal and indinavir, no change was observed in the bioavailability of indinavir (Sandhu et al., 2003).

It is important to note that there is some variation on the results obtained for the in vitro and in vivo evaluations of the pharmacokinetic interactions among natural health products and ARVs and those obtained from clinical studies. One possibility could be the pharmacogenetic influence on the clinical studies that is absent in both in vitro and in vivo studies.

Although in most cases the pharmacokinetic interactions of ARVs with other products are done with a single ARV it is rare for an ARV therapy to include a single ARV; it normally contains combinations of two and most commonly three antiretroviral drugs. This makes the study of the interaction of these different combinations of ARV drugs with the different natural health products and complementary medicines a more complex task. It is however valuable to know the metabolic route of each natural health product and complementary medicine so that a better judgment can be made of what to take and when, to avoid treatment failure and worse still, to prevent the development of resistance to treatment by HIV-infected individuals. Tarirai et al. (2010) suggested that certain NHPs and complementary medicines could be administered either 2 hours before or 2 hours after the drug for which an interaction is known to exist. 
There are some reports on the beneficial interaction between some natural health products in helping to reduce the progression of HIV/AIDS either by targeting the HIV virus replication or by alleviating the toxic effects associated with the intake of ARVs; more scientific and clinical data is however still needed. Antioxidants play an important part in maintaining a healthy immune system and controlling oxidative stress. The presence of oxidative stress in HIV-infected individuals is known to contribute to the progression of the disease. Although the role of plant-derived antioxidants including flavanoids and proanthocyanins in helping to reduce oxidative stress has been suggested in HIV-infected individuals there is not enough evidence to confirm this to be the case (Cos et al., 2004). While a dietary intervention with antioxidants could be considered as a cost-effective strategy in the HIV treatment the metabolic route of these plant derived antioxidant compounds need to be properly evaluated to prevent any pharmacokinetic interactions with ARV drugs.

While limited information is available on the pharmacokinetic interactions between natural health products and other complementary and alternative medicines with ARV drugs often healthcare providers and patients perceive their concurrent administration unlikely to be harmful. In addition physicians are often not aware of the patients' use of natural health products or complementary medicines and are therefore not able to discuss with the patient the best way to combine the use of conventional medicine with unconventional therapies, including herbal medicines.

An aspect that is particularly important in developing countries, where the level of malnutrition is very high, is the possible effect that fortified staple foods can have on HIVinfected individuals by the simultaneous intake of ARVs. A similar situation has been reported with the co-administration of certain antibiotics, like tetracyclines and fluoquinolones, which bind to the iron and calcium in foods and in dietary supplements (Tarirai et al., 2010). Awareness should also be made with the concurrent intake of certain fortified foods. Tuntipopipat et al. (2006) reported a reduction in the absorption of iron by a group of healthy females that consumed iron-fortified foods together with Chilli pepper. The iron was bound to capsaicin, the polyphenos that are found in Chilli (Capsicum annum). To avoid these types of interactions the intake of certain herbal preparations should be administered a couple of hours before or after the interacting drug. This approach will prevent the development of drug resistance that can be the result of reduced clinical efficacy of the drug.

In South Africa food fortification programmes have been implemented especially in schools in order to overcome some of the nutrient deficiencies including micronutrient deficiencies linked to poverty and malnutrition. These deficiencies are being addressed by the mandatory fortification of table salt with iodine and maize meal and bread flour with a vitamin mixture and mineral mixture (Vorster, 2010). The pharmacokinetic evaluations of fortified foods need to be included in future research to prevent treatment failure or development of resistance by any HIV-infected individuals.

\subsection{Screening of natural health products and nutrients in foods for metabolism with CYP450 enzymes}

CYP450 enzymes are biocatalytic enzymes crucial for the metabolisms of drugs and toxins. The CYP450 system is genetically determined and as such it varies among people. The polymorphic forms of CYP450 genes are responsible for the development of a significant number of adverse drug reactions (Ingelman-Sundberg, 2004). This constitutes an additional challenge for health practitioners to achieve the optimum level of a drug. There are some 
commercial tests available that can determine the individual's CYP450 activity based on the analysis of a blood-derived DNA sample. This test is available for CYP2D6 and CYP2C19 enzymes which cover about $25 \%$ of all drugs (Ingelman-Sundberg, 2004) but do not include CYP3A4, 5 and 7 enzyme families through which the currently used ARVs are metabolized. The pharmacogenetic profile of individuals on ARV treatment is an important factor in the evaluation of safety and risk of co-administered drugs with certain herbal/plant products; however this was outside the scope of this review.

CYP450 analysis of herbal and plant natural products commercially available as natural health products or complementary medicines was reported by Strandell et al., (2004) using in vitro inhibition assays. Extracts were prepared from these products and the level of inhibition of CYP3A4, 2D6 and 2C19 enzyme activities identified. Based on the levels of inhibition obtained for each of the products additional tests could be suggested including in vivo interaction studies. The screening of the active ingredients of 49 herbal species for the potential inhibition of CYP3A4 was reported by Lee et al., (2007) using a CYP HerboChip ${ }^{\circledR}$. As these screening platforms become available it facilitates future research to determine the potential interactions between commonly used herbal medicines, natural foods and antiretroviral agents in order to prevent treatment failure and resistant HIV in HIV-infected individuals.

\subsection{The way forward}

Reliance on traditional herbal medicine by the majority of the population in Sub-Saharan Africa and the global increase in the use of natural products it will most probably contribute in an increase in the pharmacokinetic interactions between herbs and drugs; between natural ingredients found in foods, in natural health products or in complementary medicines and drugs; between drug and drug; and between herb and herb. As most of the herbs and natural products are categorized as foods it suggests that they did not have to follow the rigorous safety and efficacy regulations that are expected from prescription drugs including ARVs.

Knowledge of the potential interactions between drugs, ARVs and plant derived products is very limited and more research needs to be done to identify potential harmful interactions. The information generated needs to be documented and made available to traditional healers, health practitioners and also to the HIV-infected individuals so that they can understand the impact that those interactions can have on the development of drug resistance and treatment failure.

Caution should be exercised when evaluating the pharmacokinetic results of the plant extracts and herbal extracts since the extractions of the different constituents are not chemically standardized. Depending on the protocols used to extract the metabolic components of a particular plant a different result may be produced which in turn will generate a different outcome with the ARV drug concentrations. Moreover the same product that is available from a different 'brand' may produce a different result. While the production of drugs and other pharmaceutical agents have a defined chemical structure and molecular formula regardless of the manufacturer, there are many constituents in a particular plant extract. In addition their profiles are not only affected by the extraction method but can also be influenced by the plants' growing conditions, geographical location, part of the plant used, post-harvesting treatment and formulation among many other factors (Ngo et al., 2009). Although this process is very complex it should not deter from the implementation of a rigorous evaluation of the constituents in foods derived from plants so 
that appropriate corrective steps can be taken to address the concerns of individuals taking certain ARV medications concomitantly with certain foods.

The first step in the study of the pharmacokinetic interactions with ARV drugs should be to perform in vitro tests of the constituents of natural health products, complementary medicines, herbal products and indigenous foods. This approach allows the profiling of secondary metabolites of many natural products enabling the identification of any interactions in the modulation of CYP450 enzyme system before establishing the need to conduct more time-consuming and costly clinical studies. Furthermore the rigorous in vitro characterization of any dietary substance should be undertaken before embarking on a clinical drug-diet interaction study.

The way forward is therefore to make the healthcare givers, doctors, nurses and school dietitians aware of the possible food-drug interactions that occur through the formation of insoluble complexes in the gastrointestinal tract that can reduce the bioavailability of the coadministered ARV drugs.

\section{Conclusion}

Herbal medicines and other dietary supplements such as vitamins are commonly used as alternative medicines in Europe, America and Africa. In Africa herbal medicines are an integral part of the treatment regimen of most HIV-infected patients. However not enough information is available on the possible interactions between commonly used herbal medicines and antiretroviral agents. Furthermore many of the HIV-infected patients on antiretroviral therapy often do not report the concomitant usage of herbal medicines to their physicians; on the other hand not always the physicians are aware of the risk for herb-ARV interactions and therefore do not discuss the simultaneous intake of herbal medications with ARVs with their patients. Greater awareness and education is required to show that when herbal medicines and ARVs are metabolized by the same CYP450 enzymes significant drug interactions can occur. Those interactions can result in either induction or inhibition of the CYP450 enzymes that are involved in ARV metabolism. While induction could lead to subtherapeutic plasma levels of the ARV leading to possible therapeutic failure and enhanced risk of developing ARV drug resistance, inhibition could lead to high ARV plasma levels with the risk of possible serious side effects.

A contribution to the HIV-infected persons in developing countries is to continue to determine the CYP enzyme system used by the foods and remedies that they consume and this way try to reach an optimal plasma level of the ARVs in HIV-infected individuals. Although in vitro evaluations of the potential interactions of plant extracts from foods and herbs have been reported this represents only a small fraction of what is used by the different population groups in Africa including South Africa. The work that we have initiated covers a selection of indigenous foods and traditional medicines consumed by the resource poor communities in the region and it will contribute towards increased awareness of potential food-drug interactions; if the foods tested are found to be substrates for CYP450, especially CYP3A4, the potential interaction with some of the ARVs can be anticipated and the appropriate adjustments made to the ARV treatment; it will lead to a more effective ARV treatment and it will improve the quality of life of the people living with HIV/AIDS. Furthermore the knowledge being generated in this and similar studies will help prevent the development of drug resistance by people on HIV-treatment through the 
consumption of foods and food-related products that are modulated by the same CYP450 system of the ARVs.

\section{References}

Aiyegoro, O.A. \& Okoh, A.I. (2009). Use of bioactive plant products in combination with standard antibiotics: Implications in antimicrobial chemotherapy. Journal of Medicinal Plants Research, Vol.3, No.13, pp. 1147-1152

Anabwani, G. \& Navario, P. (2005). Nutrition and HIV/AIDS in sub-Saharan Africa: an overview. Nutrition, Vol.21, pp. 96-99

Bailey. D.G.; Dresser, G.K. \& Bend, J.R. (2003). Bergamottin, lime juice and red wine as inhibitors of cytocrome P4503A4 activity: comparison with grapefruit juice. Clinical Pharmacology and Therapeutics, Vol.73, pp. 529-537

Bibi, Z. (2008). Role of cytochrome P450 in drug interactions. Nutrition \& Metabolism, Vol.5, pp. 27, ISSN 1743-7075-5-27-37

Cos, P.; Maes, L.; Berghe, D.V.; Hermans, N.; Pieters, L. \& Vlietinck, A. (2004). Plant substances as anti-HIV agents selected according to their putative mechanism of action. J Nat Prod, Vol.167, pp. 284-293

Fernandes, A.C.; Cromarty, A.D.; Albrecht, C. \& van Rensburg, C.E. (2004). The antioxidant potential of Sutherlandia frutescens. J Ethnopharmacol, Vol.95, pp. 1-5

Hanapi, N.A.; Azizi, J.; Ismail, S. \& Mansor, S.M. (2010) Evaluation of selected Malaysian medicinal plants on phase I drug metabolizing enzymes, CYP2C9, CYP2D6 and CYP3A4 in vitro. Int J Pharmacol, Vol. 6, pp. 494-499

Ingelman-Sundberg, M. (2004). Pharmacogenetics of cytochrome P450 and its applications in drug therapy: the past, present and future. TRENDS in Pharmacological Sciences, Vol.25, No.4, pp. 193-200

Lee, L.S.; Andrade, A.S.A. \& Flexer, C. (2006). Interactions between natural health products and antiretroviral drugs: pharmacokinetic and pharmacodynamic effects. Clinical Infectious Diseases, Vol.43, pp. 1052-1059

Jang, E-H.; Park, Y-C. \& Chung, W-G. (2004) Effects of dietary supplements on induction and inhibition of cytochrome P450's protein expression in rats. Food and chemical toxicology, Vol. 42, pp. 1749-1756

Joubert, E.; Gelderblom, W.C.A.; Louw, A. \& de Beer, D. (2008). South African herbal teas: Aspalathus linearis, Cyclopia spp. and Athrixia phylicoides - A review. J Ethnopharmacol, Vol.119, pp. 376-412

Kamatou, G.P.P.; Viljoen, A.M.; van Vuuren, S.F. \& van Zyl, R.L. (2006) In vitro evidence of antimicrobial synergy between Salvia chamelaeagnea and Leonotis leonurus. South African Journal of Botany, Vol.72, pp. 634-636

Lee, S.S.; Zhang, B.; He, M.L.; Chang, V.S.C. \& Kung, H.F. (2007). Screening of active ingredients of herbal medicine for interaction with CYP450 3A4. Phytotherapy Research, Vo. 21, pp. 1096-1099

Mannel, M. (2004). Drug interactions with St John's wort: mechanisms and clinical implications. Drug Saf, Vol.27, pp. 773-797

Markowitz, J.S.; Devane, C.L.; Chavin, K.D.; Taylor, R.M.; Ruan, Y. \& Donovan, J.L. (2003). Effects of garlic (Allium sativum L.) supplementation on cytochrome P450 2 D6 and 
3A4 activity in healthy volunteers. Clin Pharmacol Ther, Vol.74, No.2, pp. $170-177$

Matsuda, K.; Nishimura, Y.; Kurata, N.; Iwase, M. \& Yasuhara, H. (2007) Effects of continuous ingestion of herbal teas on intestinal CYP3A in the rat. Journal of Pharmacological Science, Vol.103, pp.214-221

Mills, S. \& Bone, K. (2000). Principles and practice of phytotherapy: modern herbal medicine. Edinburgh; New York: Churchill Livinsgtone

Mills, E.; Foster, B.C.; van Heeswijk, R.; Phillips, E.; Wilson, K.; Leonard, B.; Kosuge, K. \& Kanfer, I. (2005a). Impact of African herbal medicines on antiretroviral metabolism. AIDS, Vol.19, pp. 95-97

Mills, E.; Cooper, C.; Seely, D. \& Kanfer, I. (2005b). African herbal medicines in the treatment of HIV: Hypoxis and Sutherlandia. An overview of evidence and pharmacology. Nutrition Journal, Vol.4, pp.e19

Ngo, N.; Yan, Z.; Graf, T.N., Carrizosa, D.R.; Kashuba, A.D.M.; Dees, E.C.; Oberlies, N.H. \& Paine, M.F.(2009). Identification of a cranberry juice product that inhibits enteric CYP3A-mediated first-pass metabolism in humans. Drug Metabolism and Disposition, Vol.37, pp.514-522

Piscitelli, S.C.; Burstein, A.H.; Chaitt, D.; Alfaro, R.M. \& Falloon, J. (2000). Lancet, Vol.355, pp. $547-548$

Piscitelli, S.C.; Burstein, A.H.; Weldon, N.; Gallicano, K.D. \& Falloon, J. (2002). Clin Infect Dis, Vol.34, pp. 234-238

Roche, n.d. AmpliChip CYP450 Test. 2011-04-07. Available from: www.roche.com

Sandhu, R.S.; Prescilla, R.P.; Simonelli, T.M. \& Edwards, D.J. (2003). Influence of goldenseal root on the pharmacokinetics of indinavir. J Clin Pharmacol, Vol.43, pp. 1283-1288

Slain, D.; Amsden, J.R.; Khakoo, R.A.; Fisher, M.A.; Lalka, D. \& Hobbs, G.R. (2005). Effect of high-dosevitamin $C$ on the steady-state pharmacokinetics of the protease inhibitor indinavir in healthy volunteers. Pharmacotherapy, Vol. 25, pp. 165-170

South African Department of Health. 2011-06-06. Available from: www.doh.gov.za/docs/misc/hiv/manual/pharmacology_art.pdf

Strandell, J.; Neil, A. \& Carlin, G. (2004). An approach to the in vitro evaluation of potential for cytochrome P450 enzyme inhibition from herbals and other natural remedies. Phytomedicine, Vol.11, pp.98-104

Tarirai, C.; Viljoen, A.M. \& Hamman, J. H. (2010). Herb-drug pharmacokinetic interactions reviewed. Expert Opin. Drug Metab Toxicol, Vol.6, No.12, pp. 1515-1538

Tuntipopipat, S.; Judprasong, K.; Zeder, C.; Wasantwisut, E.; Winichagoon, P.; Charoenkiatkul, S.; Hurrel, R. \& Walczyk, T. (2006). Chilli, but not turmeric, inhibits iron absorption in young women from iron-fortified composite meal. J Nutr, Vol.136, No.12, pp. 2970-2974

Van den Bout-van den Beukel C.J.; Koopmans, P.P.; van der Ven, A.J.; De Smet, P.A. \& Burger, D.M. (2006). Possible drug-metabolism interactions of medicinal herbs with antiretroviral agents. Drug Metab Rev, Vol.38, No.3, pp. 477-514

Vorster, H.H. (2010). The link between poverty and malnutrition: A South African perspective. Health SA Gesondheid Vol.15, pp. e1 
Wilkinson, G.R. (2005). Drug metabolism and variability among patients in drug response. N Engl J Med, Vol.352, No.21, pp. 2211-2221. 


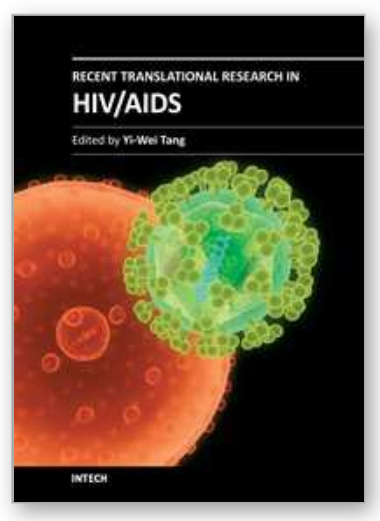

\author{
Recent Translational Research in HIV/AIDS \\ Edited by Prof. Yi-Wei Tang
}

ISBN 978-953-307-719-2

Hard cover, 564 pages

Publisher InTech

Published online 02, November, 2011

Published in print edition November, 2011

The collective efforts of HIV/AIDS research scientists from over 16 countries in the world are included in the book. This 27-chapter Open Access book well covers HIV/AIDS translational researches on pathogenesis, diagnosis, treatment, prevention, and also those beyond conventional fields. These are by no means inclusive, but they do offer a good foundation for the development of clinical patient care. The translational model forms the basis for progressing HIV/AIDS clinical research. When linked to the care of the patients, translational researches should result in a direct benefit for HIV/AIDS patients.

\title{
How to reference
}

In order to correctly reference this scholarly work, feel free to copy and paste the following:

Eugenia Barros (2011). Interaction of Traditional Remedies Against HIV, Nutrients and ARVs, Recent Translational Research in HIV/AIDS, Prof. Yi-Wei Tang (Ed.), ISBN: 978-953-307-719-2, InTech, Available from: http://www.intechopen.com/books/recent-translational-research-in-hiv-aids/interaction-of-traditionalremedies-against-hiv-nutrients-and-arvs

\section{INTECH}

open science | open minds

\section{InTech Europe}

University Campus STeP Ri

Slavka Krautzeka 83/A

51000 Rijeka, Croatia

Phone: +385 (51) 770447

Fax: +385 (51) 686166

www.intechopen.com

\section{InTech China}

Unit 405, Office Block, Hotel Equatorial Shanghai

No.65, Yan An Road (West), Shanghai, 200040, China

中国上海市延安西路65号上海国际贵都大饭店办公楼 405 单元

Phone: +86-21-62489820

Fax: +86-21-62489821 
(C) 2011 The Author(s). Licensee IntechOpen. This is an open access article distributed under the terms of the Creative Commons Attribution 3.0 License, which permits unrestricted use, distribution, and reproduction in any medium, provided the original work is properly cited. 